\title{
Ancient and Current Distributions of Erythrina crista-galli L. (Fabaceae) in South America
}

\author{
Luciano Moura de Melloㄹ (D), Rafael Lemos² (D), Alcemir Marques² (D), \\ Valdir Marcos Stefenon ${ }^{2}$ \\ ${ }^{1}$ Colégio Militar de Santa Maria, Santa Maria/RS, Brasil \\ ${ }^{2}$ Universidade Federal do Pampa - UNIPAMPA, São Gabriel/RS, Brasil
}

\begin{abstract}
Erythrina crista-galli is a native tree from South America with an important role on pharmaceutical studies. The objective of this study was to model the ancient and current ecological niches distribution of E. crista-galli in South America, contributing to the discussion about species management and conservation. A reduction in the potential area of species occurrence was detected by comparing past and present distribution. Based on the obtained results, it is expected that this species tends to expand its frontiers if the natural dynamic of the extant populations is guaranteed in southern South America. Therefore, management and conservation of E. crista-galli should focus on allowing the expansion of native forest formations where this species occurs. Additionally, further studies on the medicinal properties of the species may valorize and promote a higher interest in rational exploitation and conservation of E. crista-galli in its natural environment.
\end{abstract}

Keywords: maximum entropy, corticeira-do-banhado, Brazilian Pampa. 


\section{INTRODUCTION}

Habitat fragmentation associated with anthropic interference is currently the most significant event that impacts the distribution of wild populations. This occupation of spaces evidently also responds to global climatic and environmental variables to which the species may be subject (Begon et al., 2007; Brito, 2009; Cahill et al., 2012; Alexandre et al., 2013).

However, the anthropogenic climatic changes will be the main cause of extinction of species in the next 100 years, highlighting the local extinctions given by species intolerance to environmental changing factors (Cahill et al., 2012). Such event must be due to the difficulty of organisms to make physiological adjustments fast enough to adapt to the temperature increases in the time frames that should occur according to current forecasts and the fragmentation of ecosystems, in addition to numerically reducing, which impairs gene flow and reduces the genetic variability of populations
(Primack \& Rodrigues, 2001; Gotelli, 2007; Nagel et al., 2015) and population fitness (Stefenon et al., 2016).

Erythrina crista-galli L. (Fabaceae) is a native tree species in southern Brazil where it is known as Corticeira-do-banhado (Figure 1). It is also naturally distributed in Paraguay, southern Bolivia and throughout the Uruguayan and northern Argentinean territories, where it is known as Ceibo, and considered the symbol tree of these countries (Lozano \& Zapater, 2010; Nesom, 2015). This species is also naturalized in other regions of the globe, with the most representative area in the southern and southeastern regions of Africa (Hyde et al., 2017), eastern Australia (Bean, 2008) and south of the United States (Nesom, 2015).

It is a pioneer plant that may occur and even help environments with different degradation states of poor or very humid soils. Being a hygroscopic tree, it naturally and very frequently occupies areas used for agricultural activities in southern Brazil. Thus, the populations of E. crista-galli in these natural areas

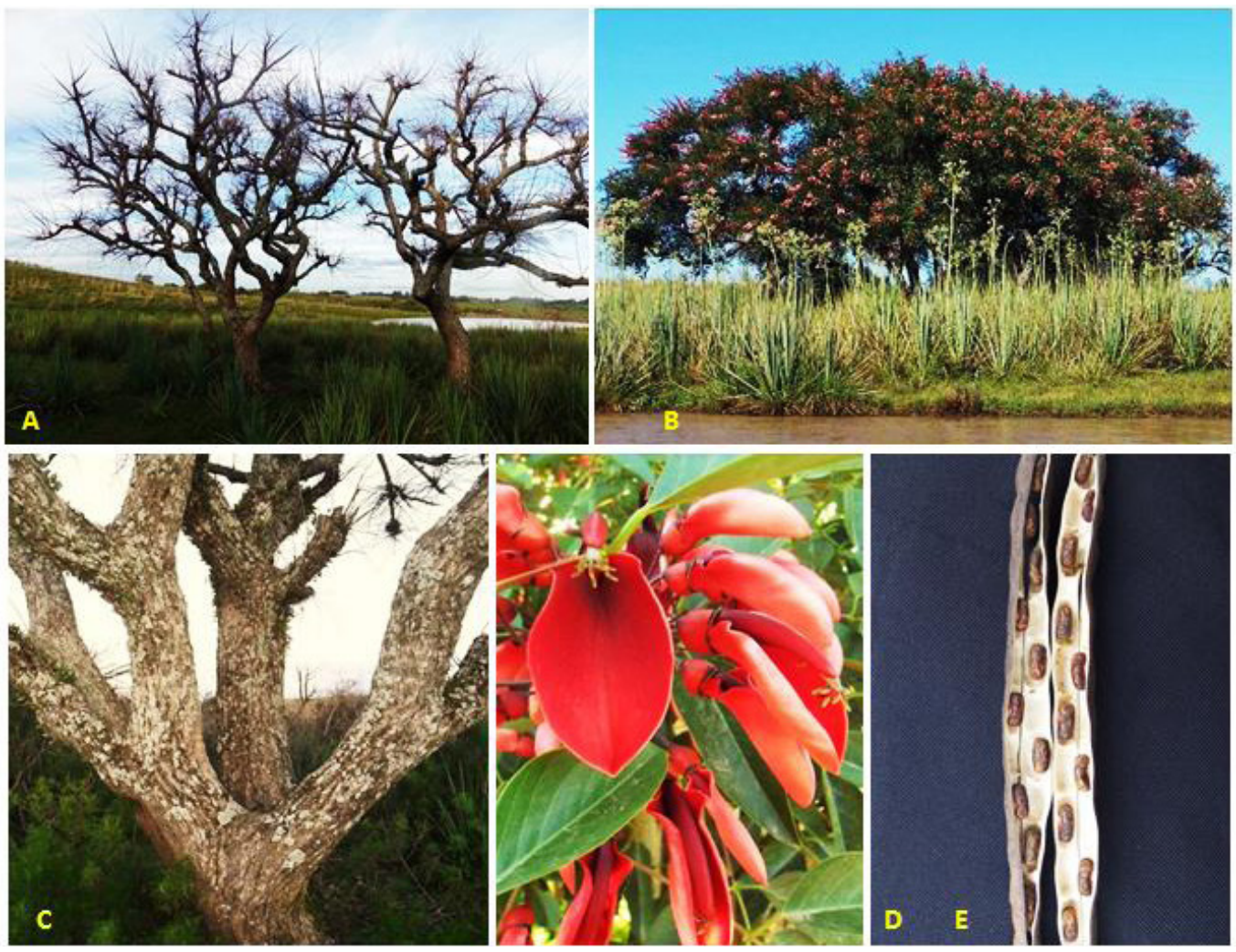

Figure 1. Erythrina crista-galli L. growing in the Pampa biome, southern Brazil.(A) Appearance during autumn-winter; (B) during flowering (spring-summer); (C) aspect of the trunk; (D) aspect of the flowers; (E) aspect of the dehiscent fruit with seeds. 
compete with agricultural activity, especially those occupied by rice cultivation and, more recently, by the cultivation of soybean (Paz \& Bassagoda, 2002).

Studies on the chemical composition of the genus Erythrina have shown interesting applications, such as anti-inflammatory properties (Weber et al., 2004). Other promising substances include bioactive alkaloids (Ito et al., 1976), flavonoids, especially isoflavonoids, pterocarpans, flavones and isoflavones (Tanaka et al., 1997). These components have promised antimicrobial activities against Escherichia coli, Staphylococcus aureus, Bacillus subtilis and Candida mycoderma (Chacha et al., 2005; Mitscher et al., 1988). Positive effects of these substances are still reported as inhibitors of cariogenic bacteria (Sato et al., 2003). Inhibitory effect of erythrin substances on plasmodial activities (Plasmodium falciparum), as well as its anti-HIV effect, is also reported (McKee et al., 1997; Andayi et al., 2006).

Knowledge of geographical distribution is fundamental to support evolutionary and ecological studies of species (Paglia et al, 2012). However, data available from the peak of the last great glaciation, occurring 22,000 years before the present (BP), can provide valuable information on the areas of occurrence of the species from that period to its occupation of the natural territories today (Bonaccorso et al., 2006). Furthermore, predictions of this distribution, based on the current qualification of its niches, can serve as important predictions of the available areas to be occupied by the species also in future scenarios, as presented by Lemos et al. (2014) for Schinus molle L., a widely distributed tree in the Pampa biome.

Aiming to direct ground surveys and contribute to management and conservation efforts of E. crista-galli, maximum entropy algorithms was utilized in this study to evaluate the ancient (20,000 years BP) and current distribution area of this species. We intended to answer the following questions: (1) is the expansion of E. crista-galli populations expected in South America under the current climatic conditions? (2) Which approaches should be used to ensure the natural dynamic and conservation of this species in South America?

\section{METHODS}

The maps of the potential distribution of Erythrina crista-galli were produced using the Maxent algorithm (Maximum Entropy Modeling of Species Geographic
Distributions), version 3.3.3 (Phillips et al., 2006), applying the basic parameters suggested by the software with the incorporation of 70 points of verified occurrence of the species populations (Supplementary File 1). Data about species distribution were recorded from Costa \& Morais (2008), Lozano \& Zapater (2010), Lazarotto et al., (2011), and the Digital Flora of Rio Grande do Sul and Santa Catarina platform (Giehl, 2012). Diva-GIS ${ }^{\circledast}$ software (Hijmans et al., 2001) version 7.5 was used for the subsequent generation of distribution maps based on the predictions generated by MaxEnt.

The quality of the model was evaluated using the Receiver Operating Characteristics (ROC) parameter that describes the sensitivity and specific aspects of the model (Phillips et al., 2006). The Area Under the Curve (AUC) was also used to gauge the sensitivity of the prediction. AUC rates varied from 0 to 1 , where values below 0.5 indicate poor performance (Peterson et al., 2008). The quality assessment of the model based on the AUC data was made by values where AUC $>0.90$ are considered excellent, $0.80>\mathrm{AUC} \leq 0.90$ are good, between $0.70>$ AUC $\leq 0.80$ are acceptable, $0.60>$ AUC $\leq 0.70$ are bad results and those obtained below $0.50>$ AUC are considered as invalid (Araújo et al., 2005).

For the present study we used data from 19 global environmental variables (BioClim) of the average period between 1950-2000 (Table 1). Climatic data were recovered from the WorldClim platform (Global Climate Database; Hijmans et al., 2005).

The base of maps used with the territorial limits of the countries was obtained from the Global Administrative Areas (GADM), version 2.8, using the datum WGS84 (GAA, 2016) with spatial resolution of 2.5 arc-seconds, representing approximately $5 \mathrm{~km}^{2}$. For the representation of the series in the maps, the probability indexes of occurrence of six frequency intervals were admitted. Modeling was performed for current climatic conditions as well as 22,000 years ago, using past environmental variables available in the Global Climate Database (Hijmans et al., 2005).

\section{RESULTS}

The sensitivity of the generated model evaluated by means of the Area Under the Curve (AUC) indicated high performance of the modeling, with an AUC value of 0.994. Practically half of the species distribution is 
Table 1. Contribution and importance of environmental factors exchange in the distribution of Erythrina crista-galli L. The factors that together contribute to more than $98 \%$ of the distribution are hightlighted in bold.

\begin{tabular}{|c|c|}
\hline Variable & Contribution (\%) \\
\hline $\mathrm{BIO} 3=$ Isothermality $(\mathrm{BIO} 2 / \mathrm{BIO} 7)\left({ }^{*} 100\right)$ & 30.5 \\
\hline BIO18 = Precipitation of Warmest Quarter & 21.2 \\
\hline BIO4 = Temperature Seasonality $\left(\right.$ standard deviation $\left.{ }^{\star} 100\right)$ & 20.4 \\
\hline BIO14 = Precipitation of Driest Month & 12.2 \\
\hline BIO1 = Annual Mean Temperature & 5.4 \\
\hline Altitude & 2.1 \\
\hline BIO6 $=$ Min Temperature of Coldest Month & 1.9 \\
\hline BIO11 = Mean Temperature of Coldest Quarter & 1.6 \\
\hline BIO16 = Precipitation of Wettest Quarter & 1.4 \\
\hline BIO15 = Precipitation Seasonality (Coefficient of Variation) & 0.8 \\
\hline BIO19 = Precipitation of Coldest Quarter & 0.7 \\
\hline BIO17 = Precipitation of Driest Quarter & 0.6 \\
\hline BIO2 = Mean Diurnal Range (Mean of monthly $(\max$ temp - min temp $))$ & 0.6 \\
\hline BIO5 = Max Temperature of Warmest Month & 0.5 \\
\hline BIO8 = Mean Temperature of Wettest Quarter & 0.2 \\
\hline BIO13 = Precipitation of Wettest Month & 0.1 \\
\hline BIO9 = Mean Temperature of Driest Quarter & 0 \\
\hline BIO12 = Annual Precipitation & 0 \\
\hline BIO10 = Mean Temperature of Warmest Quarter & 0 \\
\hline BIO7 = Temperature Annual Range (BIO5-BIO6) & 0 \\
\hline
\end{tabular}

determined by only two factors: isothermality [(factor that considers the coefficient of variation between the mean daytime amplitude (mean monthly temperature (max-min)) and variation (or amplitude) of Mean annual temperature] and the average precipitation of the warmer quarter. Five factors explain more than $89 \%$ of the species distribution (Table 1 and Figure 2). The variables mean temperature of the driest quarter (BIO9), annual precipitation (BIO12), average temperature of the hottest quarter (BIO10) and annual thermal amplitude [BIO7 (BIO5-BIO6)] do not participate significantly in the distribution of ecological niches to the studied species, according to this model.

The maps of the distribution models indicate that 22,000 years ago E. crista-galli had distribution of its niches more to the east of Rio Grande do Sul, occupying the area of the south center, including the area currently occupied by the Patos Lagoon and extending to the old coast (Figure 3 ).

The western region of Rio Grande do Sul state, on the borders between Uruguay and Argentina, was also a significant area for the distribution of the species. This area occurred to the south, occupying the extent of the present Prata's River and Prata's Delta, as much as the east occupied a significant area of the Pampa strictu sensu (following Lemos et al., 2014).

The current distribution patches in the Argentinean northwest also maintained an area more favorable to the establishment of populations in the past, generating areas more adequate to species establishment than those on the western border with Paraguay. However, without generating greater impacts in the propitious areas in the south of Bolivia, more restricted than in the other countries where the species is naturally distributed in South America.

From the distribution areas in the past, with the increase of average temperatures throughout the period and, above all, by the increase of humidity, the species seems to have moved towards south, concentrating on the extreme south Brazilian and Uruguayan territories, where it currently occupies practically the whole region (Figure 3).

At 22,000 years BP, the coastal zone of Rio Grande do Sul state, Brazil, was between 100 and $195 \mathrm{~km}$ from the current line, which in its average portion constituted extensive area of distribution of the species. As the warming progressed, the level of the Atlantic Ocean advanced through the territory to the present positions, making that the areas formerly occupied by 


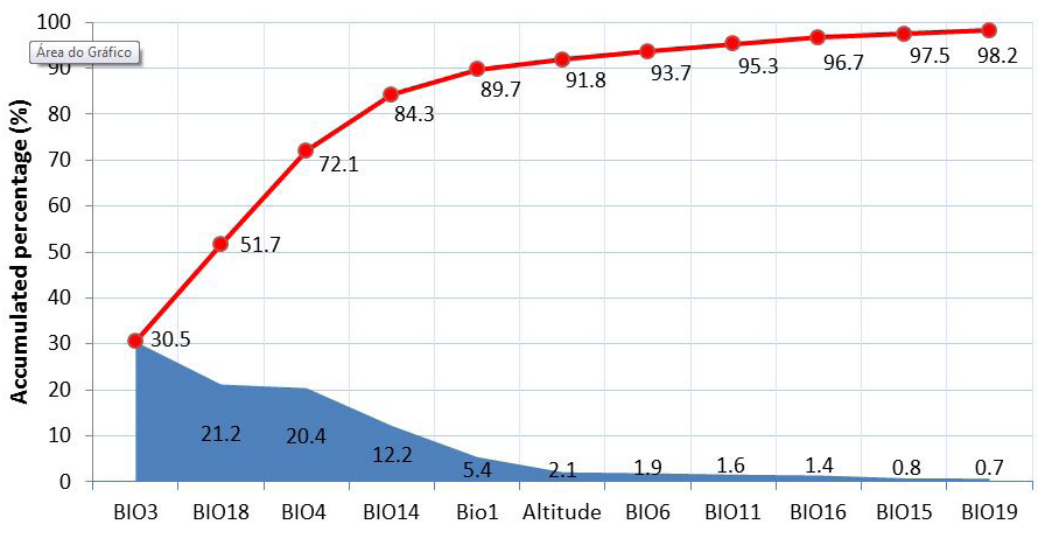

Contribution of the variables

$\%$ of the variables $\quad \longrightarrow$ accumulated value

Figure 2. Graph of the individual and cumulated contribution of the variables to Erythrina crista-galli L. in the modeling of the species ecological niches.
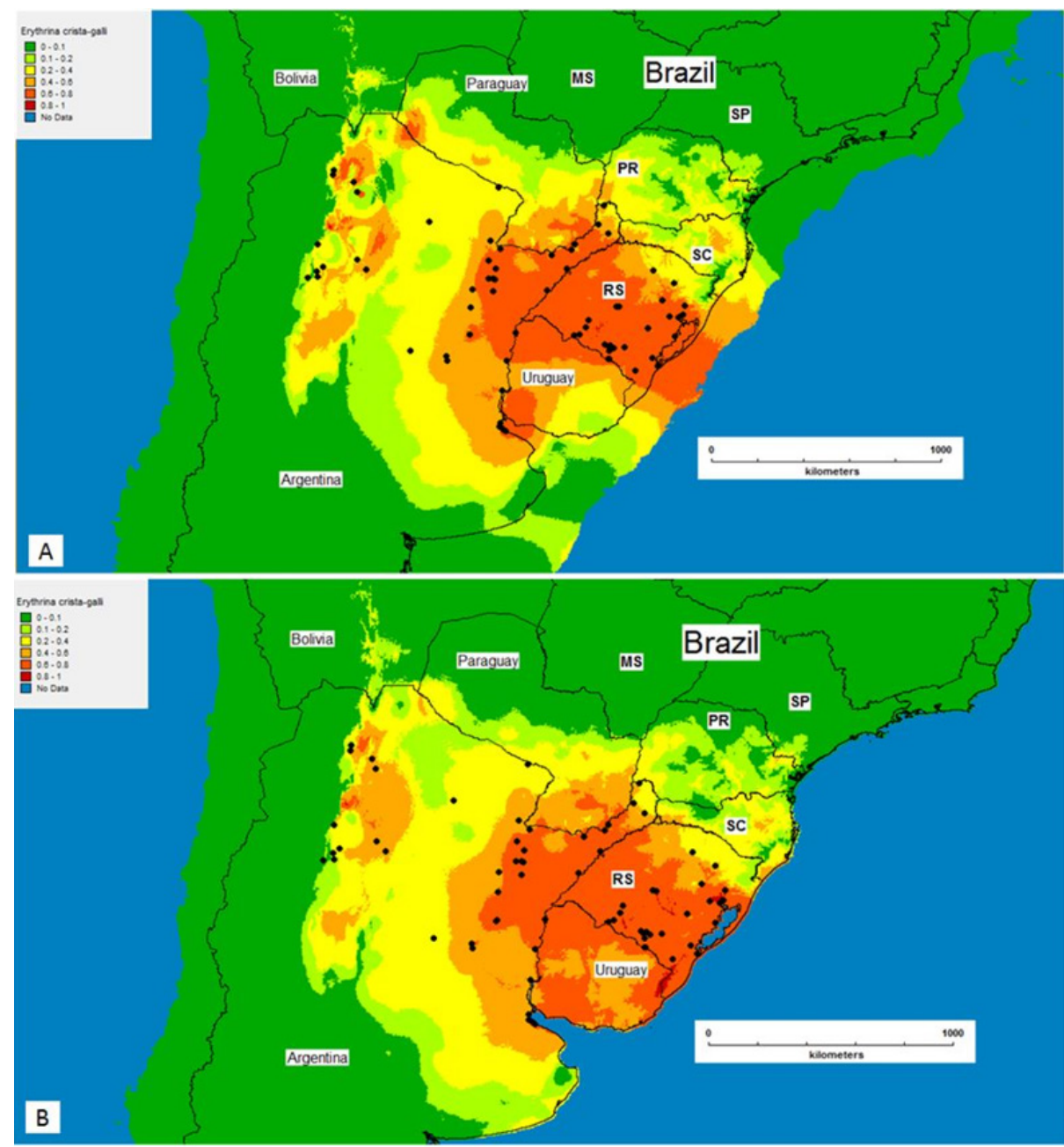

Figure 3. (A) Distribution map of Erythrina crista-galli L. 22,000 years ago BP and (B) current distribution of ecological niches for the species to South America (Brazil, Uruguay, Argentina, Paraguay and Bolivia). 

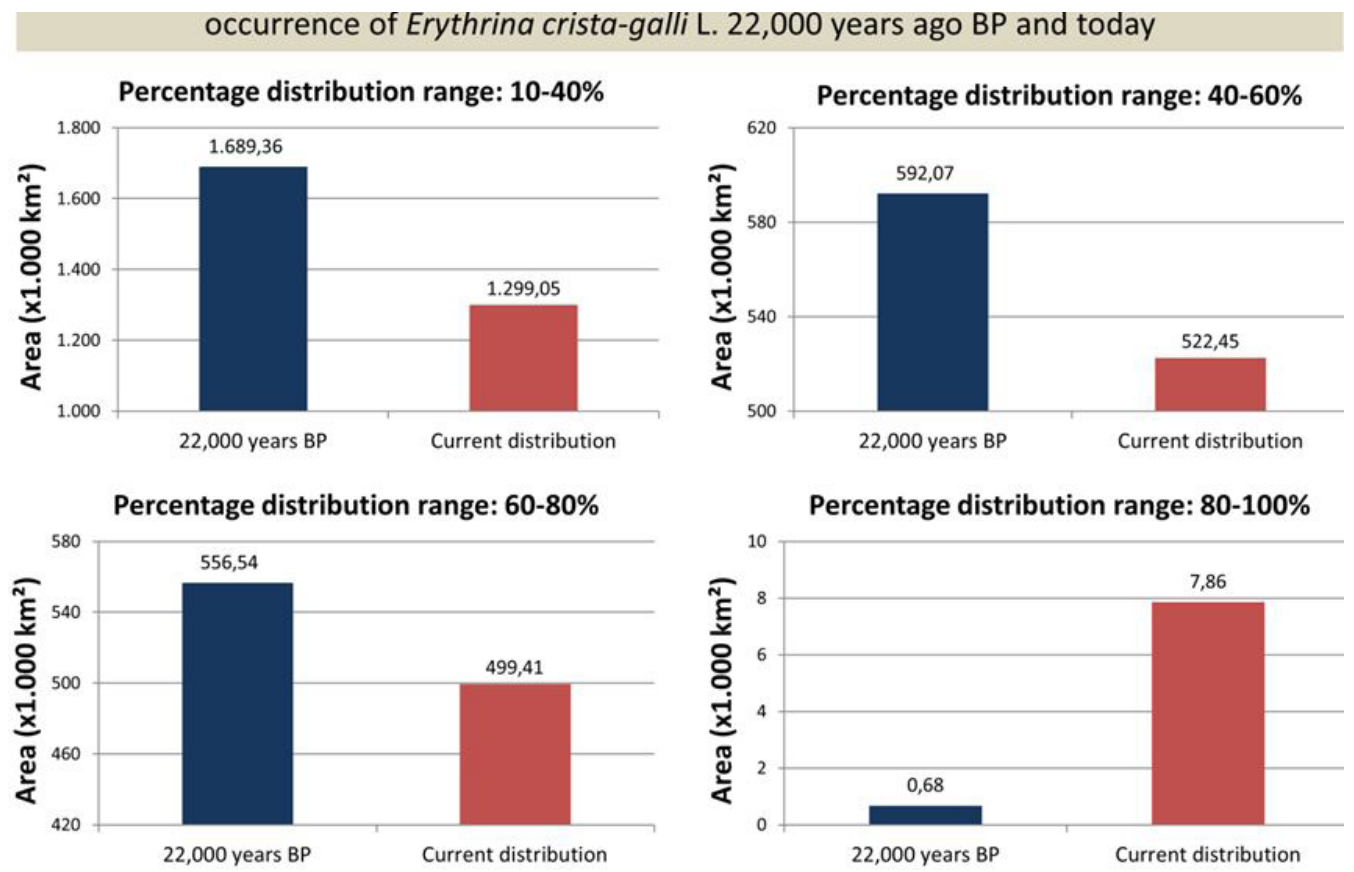

Figure 4. Distribution chart by percentage ranges of Erythrina crista-galli L. (FABACEAE) 22,000 years ago BP and the current distribution of ecological niches for the species.

the species retreated in the Brazilian and Uruguayan coasts, apparently contributing to the preservation of humidity in nearby areas and making Uruguay one of the most significant areas of the species distribution.

Throughout the natural history of the species in South America, there was a reduction of areas for all percentage bands of possibility of occurrence. This fact indicates that the increase in global temperatures since the last period of the last great glaciation, and the expectations of an even more representative increase influenced by climate change, may be a factor in reducing future areas for the species. The total areas in the two evaluated periods changed significantly, declining from approximately 2,84 million $\mathrm{km}^{2}$ at 22,000 years BP to about 2,33 million $\mathrm{km}^{2}$ at present, meaning a reduction in total areas by $21.9 \%$ (Figure 4 ).

\section{DISCUSSION}

\subsection{Is the expansion of E. crista-galli} populations expected in South America under the current climatic conditions?

Using as reference a range between $40 \%$ and $60 \%$ probability of occurrence of the species, there was a maximum of $1.5^{\circ}$ of average variation since the last glacial maximum between the parallels in the southern hemisphere, locating the registers between an approximate range of parallels -19 and $-36^{\circ} \mathrm{S}$. The comparison of the South American territory area that could have been occupied by Erythrina crista-galli in the sum of the potential intervals (Figure 3 ) allows inferring that the average global increase in temperature during the last maximum glacial (22,000 years BP) and today has significantly decreased the area of potential distribution of the species. The effects of a climate change scenario are not totally predictable, however, even optimistic analyzes indicate a tendency for warming in the coming years, which, according to the modeling carried out, points to the risks of preserving these ecological spaces and to the natural history of the species since the most important variables for their distribution are related to temperature.

Indeed, it has been shown that forest formations in the Pampa domain are found on areas where ground water accumulates (Paz \& Bassagoda, 2002) and an increasingly warmer and moister climate is considered as the main factor enabling the forest development in this biome (Behling et al., 2004).

Bellard et al. (2014) presented the threat of climatic changes to the biodiversity hotspots, and 
included the Brazilian Atlantic Forest as one of the most threatened environments of the world. Pampa biome is not considered a biodiversity hotspot, but it makes border to Atlantic Forest and is also threatened by the same risks. Its ecological dynamics suggests the expansion of forest formations and growth of savanna-like environment, and the quick changes to its physiognomy, poses a great risk to this fragile biome (Roesch et al., 2009; Lemos et al., 2014).

The reduction of potential areas over the studied time would be in the order of more than 500 thousand $\mathrm{km}^{2}$ (representing a loss of $18 \%$ of the area available in South America in the past). This indicates that predictions of the average increase in temperature caused by events of global warming can be a major impact as it speeds up the reduction in potential areas for these populations and poses a threat to the conservation of the species in its natural environments.

Based on the distribution prediction of Schinus molle, Lemos et al. (2014) proposed that the forest expansion over grassland has to be considered a natural process in the Pampa biome. Similarly, Lehmann et al. (2011) predicted a probability higher than $50 \%$ of forest growth in the Brazilian Pampa. The results of the ecological niches distribution obtained for $E$. crista-galli corroborate these predictions. Therefore, it is expected that this species tends to expand its frontiers if the natural dynamic of the extant populations is guaranteed within the Pampa biome.

\subsection{Which approaches should be used to ensure the natural dynamic and conservation of E. crista-galli in South America?}

The discussion about the conservation of the Pampa biome has been quite controversial. Considering the expansion of forest formations over the grasslands of the Pampa biome, Lemos et al. (2014) proposed that conservationist programs should motivate the establishment of conservation unities, including forest formations, and allowing the expansion of native forest tree species over the grassy areas. On the other hand, Overbeck et al. (2007) proposed to maintain the grassy vegetation and avoid forest expansion as a policy for the conservation of the Brazilian Pampa. The implication of this proposition is the controlled use of fire and grazing in the grasslands. However, Roesch et al. (2009) demonstrated that overgrazing and fire are the most critical threats to the Brazilian Pampa biome. In addition, the interaction between scientific knowledge and decision-making politics need to be reinforced as the maintenance of Brazil natural capital is still threatened (Azevedo-Santos et al., 2017).

Since E. crista-galli is a forest tree species, its conservation is directly connected to the maintenance of forest formations. Thus, considering the forest expansion over grassland as a natural process in the Pampa biome (Lemos et al., 2014), preservationist schedules for E. crista-galli should focus on allowing the expansion of native forest formations where this species occurs.

Moreover, as a species with potential medicinal properties, further studies on this topic may valorize even more this species, promoting a higher interest in rational exploitation and conservation of E. crista-galli in its natural environment as basis for important non-wood forest resources.

\section{ACKNOWLEDGEMENTS}

The authors thank to UNIPAMPA for general logistic, to CNPq for the grant (Process 302501/2017-7) and financial support (Process 442995/2014-8), to VMS and IFSul for supporting the post-doctoral internship of LMM.

\section{SUBMISSION STATUS}

Received: 13 nov., 2017

Accepted: 19 feb., 2018

\section{CORRESPONDENCE TO}

\section{Valdir Marcos Stefenon}

Universidade Federal do Pampa - UNIPAMPA, Rua Aluízio Barros Macedo, BR 290, Km 423 , CEP 97300-000, São Gabriel, RS, Brasil e-mail: valdirstefenon@unipampa.edu.br

\section{FINANCIAL SUPPORT}

CNPq, Process 302501/2017-7 and Process 442995/2014-8. 


\section{REFERENCES}

Alexandre BR, Lorini ML, Grelle CEV. Modelagem preditiva de distribuição de espécies ameaçadas de extinção: um panorama das pesquisas. Oecologia Australis 2013; 17(4): 483-508. http://dx.doi.org/10.4257/oeco.2013.1704.04.

Andayi AW, Yenesew A, Derese S, Midiwo JO, Gitu PM. Anti-plasmodial flavonoids from Erythrina sacleuxii. Planta Medica 2006; 72(2): 187-189. http://dx.doi. org/10.1055/s-2005-873200. PMid:16491458.

Araújo MB, Pearson RG, Thuiller W, Erhard M. Validation of species-climate impact models under climate change. Global Change Biology 2005; 11(9): 1504-1513. http:// dx.doi.org/10.1111/j.1365-2486.2005.01000.x.

Azevedo-Santos VM, Fearnside PM, Oliveira CS, Padial AA, Pelicice FM, Lima DP et al. Removing the abyss between conservation science and policy decisions in Brazil. Biodiversity and Conservation 2017; 26(7): 17451752. http://dx.doi.org/10.1007/s10531-017-1316-x.

Bean AR. A taxonomic revision of Erythrina L. (Fabaceae: Faboideae) in Australia. Austrobaileya 2008; 7: 641-658.

Begon M, Townsend CR, Harper JL. Ecologia de indivíduos e ecossistemas. 4. ed. Porto Alegre: Artmed; 2007. 752 p.

Behling H, Pillar VD, Orlóci L, Bauermann SG. Late Quaternary Araucaria forest, grassland (Campos), fire and climate dynamics, studied by high-resolution pollen, charcoal and multivariate analysis of the Cambará do Sul core in southern Brazil. Palaeogeography, Palaeoclimatology, Palaeoecology 2004; 203(3-4): 277-297. http://dx.doi. org/10.1016/S0031-0182(03)00687-4.

Bellard C, Leclerc C, Leroy B, Bakkenes M, Veloz S, Thuiller W et al. Vulnerability of biodiversity hotspots to global change. Global Ecology and Biogeography 2014; 23(12): 1376-1386. http://dx.doi.org/10.1111/geb.12228.

Bonaccorso E, Koch I, Peterson AT. Pleistocene fragmentation of Amazon species' ranges. Diversity \& Distributions 2006; 12(2): 157-164. http://dx.doi.org/10.1111/j.13669516.2005.00212.x.

Brito D. Análise de viabilidade de populações: uma ferramenta para a conservação da biodiversidade no Brasil. Oecologia Brasiliensis 2009; 13(3): 452-469. http:// dx.doi.org/10.4257/oeco.2009.1303.04.

Cahill AE, Aiello-Lammens ME, Fisher-Reid M, Hua X, Karanewsky CJ, Ryu HY et al. How does climate change cause extinction? London: The Royal Society; 2012. p. 1-9.

Chacha M, Bojase-Moleta G, Majinda RRT. Antimicrobial and radical scavenging flavonoids from the stem wood of Erythrina latissima. Phytochemistry 2005; 66(1): 99104. http://dx.doi.org/10.1016/j.phytochem.2004.10.013. PMid:15649516.

Costa RACV, Morais ABB. Fenologia e visitantes florais de Erythrina crista-galli L. (Leguminosae: Faboideae) em Santa Maria, RS, Brasil. Biotemas 2008; 21(2): 51-56. http://dx.doi.org/10.5007/2175-7925.2008v21n2p51.

Giehl ELH. Flora digital do Rio Grande do Sul e de Santa Catarina [online]. Porto Alegre: UFRGS; 2012 [cited 2016 Mar 10]. Available from: http://www.ufrgs.br/fitoecologia/ florars/opensp.php?img=1606

Global Administrative Areas - GAA [online]. Berkely: University of California; 2016 [cited 2016 Mar 10]. Available from: http://www.gadm.org

Gotelli NJ. Ecologia. Londrina: Planta; 2007. 260 p.

Hijmans RJ, Cameron SE, Parra JL, Jones PG, Jarvis A. Very high resolution interpolated climate surfaces for global land areas. International Journal of Climatology 2005; 25(15): 1965-1978. http://dx.doi.org/10.1002/joc.1276.

Hijmans RJ, Guarino L, Cruz M, Rojas E. Computer tools for spatial analysis of plant genetic resources data: 1. DIVAGIS. Plant Genetic Resources Newsletter 2001; 127: 15-19.

Hyde MA, Wursten BT, Ballings P, Coates Palgrave M. Flora of Mozambique [online]. 2017 [cited 2017 Aug 15]. Available from: http://www.mozambiqueflora.com/ index.php

Ito K, Haruna M, Jinno Y, Furukawa H. Studies on the Erythrina alkaloids. XI. Alkaloids of Erythrina crysta-galli Linn. Structure of new alkaloids, crystamidine. Chemical \& Pharmaceutical Bulletin 1976; 24(1): 52-55. http:// dx.doi.org/10.1248/cpb.24.52.

Lazarotto M, Beltrame R, Muniz MFB, Blume E. Maturação fisiológica de sementes de Erythrina cristagalli L. Ciência Florestal 2011; 21(1): 9-16. http://dx.doi. org/10.5902/198050982742.

Lehmann CER, Archibald SA, Hoffmann WA, Bond WJ. Deciphering the distribution of the savanna biome. The New Phytologist 2011; 191(1): 197-209. http://dx.doi. org/10.1111/j.1469-8137.2011.03689.x. PMid:21463328.

Lemos RPM, D’Oliveira CB, Rodrigues CR, Roesch LFW, Stefenon VM. Modeling distribution of Schinus molle L. in the Brazilian Pampa: insights on vegetation dynamics and conservation of the biome. Annals of Forest Research 2014; 57(2): 205-214. http://dx.doi.org/10.15287/afr.2014.272.

Lozano EC, Zapater MA. The genus Erythrina (Leguminosae) in Argentina. Darwiniana 2010; 48(2): 179-200.

McKee TC, Bokesch HR, Mccormick JL, Rashid MA, SpielVogel D, Gustafson KR et al. Isolation and characterization of new anti-HIV and cytotoxic leads from plants, marine, and microbial organisms. Journal of Natural Products 1997; 60(5): 431-438. http://dx.doi.org/10.1021/np970031g. PMid:9170286.

Mitscher LA, Gollapudi SR, Gerlach DC, Drake SD, Ve'liz EA, Ward JA. Erycristin, a new antimicrobial petrocarpan from Erythrina crista-galli. Phytochemistry 1988; 27(2): 381-385. http://dx.doi.org/10.1016/0031-9422(88)83103-0. 
Nagel JC, Ceconi DE, Poletto I, Stefenon VM. Historical gene flow within and among populations of Luehea divaricata in the Brazilian Pampa. Genetica 2015; 143(3): 317-329. http://dx.doi.org/10.1007/s10709-015-9830-9. PMid:25712879.

Nesom GL. Key to native and cultivated species of Erythrina (Fabaceae) in the USA and comments on naturalization of E. crista-galli. Phytoneuron 2015; 29: 1-8.

Overbeck GE, Muller SC, Fidelis A, Pfadenhauer J, Pillar VD, Blanco CC et al. Brazil's neglected biome: the South Brazilian Campos. Perspectives in Plant Ecology, Evolution and Systematics 2007; 9(2): 101-116. http:// dx.doi.org/10.1016/j.ppees.2007.07.005.

Paglia AP, Rezende DT, Koch I, Kortz AR, Donatti C. Species Distribution Models (SDM) in biodiversity conservation strategies and climate change ecosystem based adaptation. Natureza \& Conservação 2012; 10(2): 231-234. http://dx.doi.org/10.4322/natcon.2012.031.

Paz EA, Bassagoda MJ. La vegetación costera del SE uruguayo: ambientes y biodiversidad. Montevideo: Museo Nacional de Historia Natural y Antropologia; 2002. 6 p. (Documentos de Divulgacion; no. 5).

Peterson AT, Papes M, Soberón J. Rethinking receiver operating characteristic analysis applications in ecological niche modeling. Ecological Modelling 2008; 213(1): $63-$ 72. http://dx.doi.org/10.1016/j.ecolmodel.2007.11.008.
Phillips SJ, Anderson RP, Schapire RE. Maximum entropy modeling of species geographic distributions. Ecological Modelling 2006; 190(3-4): 231-259. http:// dx.doi.org/10.1016/j.ecolmodel.2005.03.026.

Primack RB, Rodrigues E. Biologia da conservação. Londrina: Planta; 2001. 328 p.

Roesch LFW, Vieira FCB, Pereira VA, Schünemann AL, Teixeira IF, Senna AJT et al. The Brazilian Pampa: a fragile biome. Diversity 2009; 1(2): 182-198. http://dx.doi. org/10.3390/d1020182.

Sato M, Tanaka H, Fujiwara S, Hirata M, Yamaguchi $\mathrm{R}$, Etoh $\mathrm{H}$ et al. Antibacterial property of isoflavonoids isolated from Erythrina variegata against cariogenic oral bacteria. Phytomedicine 2003; 10(5): 427-433. http:// dx.doi.org/10.1078/0944-7113-00225. PMid:12834009.

Stefenon VM, Nagel JC, Poletto I. Evidences of genetic bottleneck and fitness decline in Luehea divaricata populations from southern Brazil. Silva Fennica 2016; 50(5): 1566. http://dx.doi.org/10.14214/sf.1566.

Tanaka H, Tanaka T, Etoh H. Three pterocarpans from Erythrina crista-galli. Phytochemistry 1997; 45(4): 835838. http://dx.doi.org/10.1016/S0031-9422(97)00071-X.

Weber D, Sterner O, Anke T, Gorzalczancy S, Martino V, Acevedo C. Phomol, a new antiinflammatory metabolite from an endophyte of the Medicinal Plant Erythrina cristagalli. The Journal of Antibiotics 2004; 57(9): 559-563. http:// dx.doi.org/10.7164/antibiotics.57.559. PMid:15580955. 